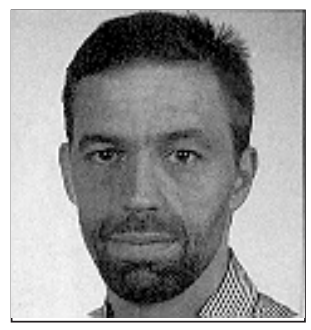

Miika Marttunen

\title{
Sähköpostin avulla perustelevaan keskusteluun?
}

\author{
Vuorovaikutus muiden ihmisten kanssa edistää \\ argumentointitaitojen ja kriittisen ajattelun kehittymistä. \\ Entä kun vuorovaikutus tapahtuu sähköpostin avulla?
}

\begin{abstract}
Yliopisto-opetukselle on asetettu seuraavia tavoitteita: Yliopistosta valmistuneen pitäisi pystyä osoittamaan asiantuntijuutta hallitsemalla oman tieteenalansa sekä lähitieteenalojen monia keskeisiä asiakokonaisuuksia. Tämän lisäksi hänen pitäisi myös osata soveltaa oppimaansa uusissa, ennalta arvaamattomissa tilanteissa sekä tietää, miten ja mistä uutta tietoa hankitaan ja millaisilla kriteereillä tietoa tulisi valikoida. Sisältöjen opettamisen ohella yliopiston tehtävänä onkin opettaa ihmiset oppimaan sekä ajattelemaan itsenäisesti ja kriittisesti.
\end{abstract}

Nykyistä yhteiskunnallista kehitystä luonnehtii siirtymä verkkoyhteiskuntaan. Verkostoituvassa nyky-yhteiskunnassa saatavilla olevan informaation määrä kasvaa ja välineet informaation hankkimiseksi kehittyvät koko ajan. Koska kaikkia uusia asioita ei ole mahdollista omaksua, taito valita informaatiota on nykyaikana erityisen tärkeätä. Järkevien valintojen tekeminen edellyttää kriittistä asennetta tietoa kohtaan sekä taitoa arvioida erilaisten asioiden ja tarkastelutapojen ansioita ja heikkouksia. Jotta informaatiotulvasta osattaisiin valita olennainen, tarvitaan itsenäisen ja kriittisen ajattelun sekä argumentoinnin taitoja.
Argumentoinnin ja kriittisen ajattelun tärkeys ilmenee myös työelämän aikuiskoulutuksessa, jossa yhtenä keskeisenä tavoitteena on kehittää organisaatioista oppivia organisaatioita. Marsick ja Watkins (1994) korostavat, että oppivassa organisaatiossa oppiminen ymmärretään jatkuvaksi prosessiksi. Jatkuvan oppimisen kannalta on tärkeätä yhteistyö ja vuorovaikutus niin organisaation sisällä kuin sen ulkopuolistenkin tahojen kanssa sekä asioiden tarkastelu kriittisesti ja perustelevasti monesta eri näkökulmasta.

Argumentoinnilla tarkoitetaan perusteltujen näkemysten esittämistä. Taitava argumentoija osaa valita ja muotoilla näkemyksensä tueksi useita sitä tukevia perusteita. Taitava argumentoija osaa myös kuvata niitä olosuhteita, joissa hänen argumenttinsa ei ole pätevä sekä osaa ja ymmärtää muuttaa kantaansa uuden tai täsmentyneen informaation valossa. Heikot argumentoijat puolestaan perustelevat näkemyksiään tukeutumalla monesti vain yhteen perusteeseen tai heidän perustelunsa on epärelevanttia, jolloin perusteet eivät tue näkemystä. (Toulmin ym. 1984.)

Argumentointitaitojen opettamista ja kehitty- 
mistä käsitelleet tutkimukset (esim. Littlefield 1995) ovat osoittaneet, että vuorovaikutus muiden ihmisten kanssa edistää argumentointitaitojen ja kriittisen ajattelun kehittymistä. Olennaista taitojen kehittymisen kannalta on se, että mielipiteiden vaihtaminen, omien näkökantojen puolustaminen ja toisten esittämien näkemysten kritisointi ohjaavat analyyttiseen ajatteluun: analysoimaan ja arvioimaan niitä väitteitä ja perusteita, joiden nojalla asioiden sanotaan olevan jollain lailla.

Vaikka yliopisto-opintojen keskeinen tavoite on edistää argumentointitaitoja ja kriittistä ajattelua, yliopisto-opiskelu sisältää melko vähän opiskelijoiden välistä vuorovaikutusta painottavia oppimistilanteita. Yliopiston yleisimpiä opiskelumuotoja ovat luentojen kuuntelu, tenttikirjojen lukeminen ja seminaarit. Luennot ja tenttiluku eivät juurikaan edistä opiskelijoiden välistä keskustelua. Seminaariopiskelussakin kriittistä keskustelua syntyy yleensä liian vähän.

Tutkimuksissa (esimerkiksi Hirsjärvi ym. 1996) on todettu, että suomalaista yliopisto-opiskelijaa vaivaa auktoriteettiusko ja jonkinlainen liiallinen kiltteys ja arkuus. Seminaarin ohjaajaa pidetään usein niin merkittävänä asiantuntijana, että hänen näkemyksiään ei ole liiemmin syytä kyseenalaistaa. Opiskelukavereiden taas pelätään monesti loukkaantuvan kriittisistä kommenteista ja huomautuksista. Suomalainen seminaariopiskelu eroaa esimerkiksi englantilaisesta seminaarista, jossa niin ohjaajan kuin opiskelutovereidenkin kritisoiminen on tavallista ja myös toivottavaa (Mauranen 1993). Monet tutkimustulokset viittaavat siihen, että suomalaisesta yliopisto-opiskelusta puuttuu argumentoiva keskustelukulttuuri tai se on ainakin kehittymätöntä. Tämä kulttuuri siirtyy yliopistosta valmistuneiden mukana helposti myös työelämään, jolloin vaarana on se, että kriittinen keskustelu jää vähäiseksi myös työelämän organisaatioissa.

Keskustelevan opiskelukulttuurin edistämiseen suomalaisessa yliopisto-opiskelussa tulisi selvästikin kiinnittää nykyistä enemmän huomiota.

\section{Uusi informaatioteknologia avuksi}

Informaatioteknologian, kuten sähköpostin, nopea kehittyminen on helpottanut paitsi informaation välittämistä ja saatavuutta, myös maailmanlaajuista ihmisten välistä kommunikointia. Verkostoituminen erityisesti sähköpostin avulla kontakteja luomalla ja ylläpitämällä yleistyy koko ajan.

Kun tarkastellaan sähköpostia kommunikointifoorumina, siitä voidaan löytää monia vuorovaikutuksen luomista ja ylläpitämistä helpottavia ominaisuuksia. Ensiksikin sähköpostikirjeitä voi laatia ja lukea silloin, kun se itselle parhaiten sopii. Sähköpostin käyttö on näin mahdollista sovittaa joustavasti sellaisen työskentelyn lomaan, joka edellyttää tietyssä paikassa olemista tiettyyn aikaan.

Toiseksi sähköpostia on luonnehdittu demokraattiseksi ja tasa-arvoiseksi viestimeksi. Sähköpostin käyttäminen ei edellytä välitöntä kontaktia muiden kanssa ja sähköpostikeskusteluihin on tarvittaessa mahdollista osallistua myös anonyyminä. Tällöin esimerkiksi keskustelijoiden sukupuoli, ulkonäkö, ammattiasema, koulutustaso, tai esiintymistaito eivät juurikaan vaikuta vuorovaikutustilanteeseen. Monet tällaiset ei-kielelliset tekijät aiheuttavat välittömissä vuorovaikutustilanteissa, niin opintojen aikana kontaktiopetuksessa kuin myös erilaisissa työelämän vuorovaikutustilanteissa sen, että puheaika ei jakaudu tasaisesti osallistujien kesken. Usein käy niin, että esiintymistaitoiset tai -haluiset tai korkeammassa ammattiasemassa olevat henkilöt hallitsevat keskustelua, kun taas aremmat tai alemman ammatillisen statuksen omaavat eivät uskalla avata suutaan.

Kolmanneksi sähköpostikielen epämuodollisuutta voidaan pitää vuorovaikutuksen aikaansaamista helpottavana tekijänä. Sähköpostikieltä on luonnehdittu kirjoitetuksi puheeksi (Tella 1992): sähköpostiteksti on yleensä jonkin verran strukturoidumpaa ja harkitumpaa kuin tavallinen puhe, sisältäen kuitenkin monesti puhekielen ilmaisuja ja epätäsmällisyyk- 
siä. Sähköpostikirjoituskulttuurille onkin ominaista se, että tekstin ei tarvitse olla viimeisteltyä, vaan yleensä riittää, että asia tulee sanotuksi. Käytettäessä sähköpostia ajatukset täytyy kuitenkin muotoilla tekstiksi, jolloin sanomasta tulee harkitumpaa ja työstetympää kuin puhekieli.

Tutkimusten mukaan (Ruberg ym. 1996; Collins 1997) erityisesti opiskelijoiden välinen vuorovaikutus on lisääntynyt sähköpostiympäristössä. Tämä johtunee paljolti juuri siitä, että kommunikoinnin tasa-arvoisuus ja epämuodollisuus alentavat kynnystä esittää kysymyksiä, vastata kysymyksiin, esittää omia mielipiteitä sekä kommentoida ja kritisoida muiden esittämiä näkemyksiä. Sähköpostia onkin tästä syystä käytetty argumentoivan kriittisen keskustelun välineenä (esim. Pugh 1993).

Tutkimustietoa sähköpostin soveltuvuudesta argumentointitaitojen ja kriittisen ajattelun kehittämiseen on kuitenkin vähän. Seuraavassa kuvataan Jyväskylän yliopistossa toteutettua tutkimusta ja opetuskokeilua, jossa yliopistoopiskelijat harjoittelivat argumentoivaa kriittistä keskustelua sähköpostiympäristössä. (ks. lähemmin Marttunen 1997a, 1997b.)

\section{TUTKIMUKSEN TOTEUTUS}

\section{Opetusjärjestelyt}

Kuusi viikkoa kestänyt sähköpostiopetuskokeilu järjestettiin Jyväskylän yliopiston kasvatustie- teen laitoksella syyslukukaudella 1990. Kokeiluun osallistui 31 vapaaehtoista, valtaosin yliopisto-opintojensa alkuvaiheessa olevaa opiskelijaa. Lisäksi kaksi opintojensa loppuvaiheessa ollutta opiskelijaa toimi tutoreina. Opiskelijat suorittivat kasvatussosiologian perusopintojakson harjoittelemalla argumentoivaa kriittistä keskustelua sähköpostin avulla. Vertailuryhmän opiskelijat $(n=193)$ eivät harjoitelleet argumentointia, vaan suorittivat opintojakson itsenäisesti tenttimällä kirjat ja luennot.

Sähköpostiopiskelijat jaettiin neljään ryhmään: kahteen tutor-johtoiseen ja kahteen opiskelijoiden itseohjautuvuuteen perustuvaan ryhmään. Opiskelijat harjoittelivat argumentointia laatimalla kurssisisältöihin liittyviä sähköpostikirjeitä, jotka he lähettivät ryhmänsä muille opiskelijoille ja tutorille. Kirjeissään opiskelijat esittivät omia perusteltuja näkemyksiään sekä kommentoivat muiden opiskelijoiden kirjeitä. Tutor-johtoisissa ryhmissä tutor laati keskusteluteemat, suuntasi keskusteluja ja antoi opiskelijoille sisällöllistä palautetta. Opiskelijoiden itseohjautuvuuteen perustuvissa ryhmissä opiskelijat päättivät itse keskusteluaiheista ja huolehtivat keskustelun etenemisestä tutorin toimiessa etupäässä kanssaopiskelijan roolissa.

\section{Aineisto ja analyysit}

Sekä sähköpostiopiskelijoiden että itsenäisesti opiskelleiden argumentointitaitojen taso mitattiin kurssin jälkeen. Mittauksessa selvitettiin opiskelijoiden taitoa a) kommentoida kirjallisia argumentteja, joissa oli esitetty jokin väit-

\footnotetext{
Tutkimusasetelma

SÄHKÖPOSTIOPISKELIJAT $(\mathrm{n}=31)$

Tutorjohtoinen ryhmä 1

Tutorjohtoinen ryhmä 2

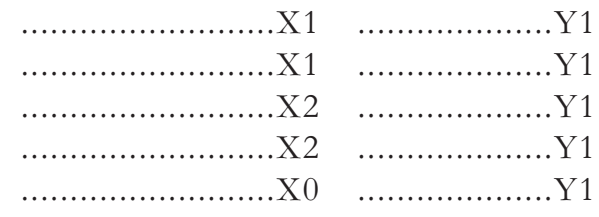

Itseohjautuva ryhmä 1

Itseohjautuva ryhmä 2

ITSENÄISESTI OPISKELLEET $(\mathrm{n}=193)$

$\mathrm{X} 0$

X1: Argumentoivaa keskustelua oppisisällöistä tutorin johdolla

X2: Argumentoivaa keskustelua oppisisällöistä itseohjautuvasti

X0: Tenttilukua

Y1: Loppumittaus
} 
tämä ja sille perustelut, b) analysoida argumentoivia tekstikatkelmia etsimällä niistä keskeiset väittämät ja niiden perustelut sekä vetää perusteiden pohjalta johtopäätöksiä sekä c) perustella itse muotoilemiaan väittämiä.

Argumenttien kommentointeja analysoitiin tarkastelemalla kommenttien erittelevyyttä ja argumentoivuutta. Väittämien analyyseissä tarkasteltiin väittämien selkeyttä ja sitä, kuinka hyvin tekstistä etsitty väittämä vastasi tekstin keskeisintä väittämää. Perustelujen analyyseissä oltiin kiinnostuneita perustelun täsmällisyydestä ja kattavuudesta ja johtopäätösten analyyseissä tarkasteltiin sitä, kuinka oikeutettuja ja johdonmukaisia johtopäätökset olivat. Tuloksia vertailtiin sähköpostiopiskelijoiden ja kurssin tenttimällä opiskelleiden kesken sekä eri tavoin toteutettuun sähköpostiopiskeluun osallistuneiden kesken.

Sähköpostiopiskelijoille lähetettiin myös kyselylomake ja tutorit haastateltiin. Opiskelijoita ja tutoreita pyydettiin arvioimaan sähköpostikeskustelujen luonnetta sekä sähköpostiopiskelua opiskelumuotona. Lisäksi opiskelijoiden sähköpostikirjeet analysoitiin. Analyyseissä selvitettiin kirjeiden argumentaation ja vastaargumentaation tasoa sekä niihin yhteydessä olevia tekijöitä.

\section{TULOKSET JA JOHTOPÄÄTÖKSET}

\section{Opiskelijat argumentoivat heikosti}

Tulosten mukaan opiskelijoiden $(n=224)$ argumentointitaidot olivat heikot. Opiskelijoiden keskiarvot argumentointitaitojen tasoa mitanneilla 12:1la muuttujalla vaihtelivat välillä .25$.90\left(\min _{(0)}, \max _{(2)}\right)$. Taitojen heikkoutta ilmensi myös se, että sähköpostiopiskelijoiden laatimien kirjeiden $(\mathrm{n}=441)$ argumentaation taso osoittautui niinikään matalaksi (ka.=.62, $\min _{(0)}$, $\left.\max _{(2)}\right)$. Tulokset osoittavat, että argumentoinnin ja kriittisen ajattelun taitojen opettamiseen täytyy suomalaisessa yliopisto-opetuksessa kiinnittää enemmän huomiota.

Opiskelijoiden argumentointitaitojen puutteel- lisuuteen on vaikuttanut se, että heistä valtaosa oli yliopisto-opinnoissaan vielä alkuvaiheessa, mistä johtuen heidän taitonsa esittää perusteltuja näkemyksiä ei ollut vielä ehtinyt kehittyä. Tätä väitettä tukee Terenzinin ym. (1995) tutkimus, jonka mukaan argumentointi- ja kriittisen ajattelun taidot kehittyvät pitkän ajanjakson kuluessa erityisesti silloin, kun yliopistoopintojen aikana vähitellen sosiaalistutaan akateemiseen perustelevaan keskus-telukulttuuriin. Argumentointitaitojen kehittyminen on kuitenkin myös kulttuurisidonnainen ilmiö: opiskelukäytänteet ja -kulttuurit niin yliopistoopinnoissa kuin myös yliopistoa edeltävien opintojen aikana ovat erilaisia eri maissa. Argumentointitaitojen tason heikkouteen tässä tutkimuksessa lieneekin vaikuttanut myös tutkittujen koulutushistoria: suomalaisessa keski-asteen opiskelussa, toisin kuin esimerkiksi pohjoisamerikkalaisessa opiskelussa, ei juurikaan painoteta kriittisen keskustelun ja reflektoivan ajattelun harjoittelemista, vaan pikemminkin faktatietojen opiskelua. Tutkimustulokset antavatkin aiheen pohtia suomalaisen yliopisto-opiskelun kehittämistarpeiden ohella myös sitä, pitäisikö kriittistä ajattelua ja mielipiteiden perustelemista harjoitella jo korkea-astetta edeltävien opintojen aikana nykyistä enemmän.

\section{Kriittisyys oli vähäistä}

Kriittinen keskustelu ja vuorovaikutus sähköpostiopiskelijoiden välillä osoittautui vähäiseksi. Kritiikin vähyyttä ilmentää se, että vain 13 prosenttia opiskelijoiden sähköpostikirjeistä sisälsi yhden tai useamman sellaisen näkemyksen, jossa kiistettiin kanssaopiskelijan, tutorin tai kurssikirjassa esitetty väite. Opiskelijoiden välisen vuorovaikutuksen vähyyttä kuvaa se, että kirjeistä valtaosassa $(58 \%)$ ei ollut viitattu kanssaopiskelijoiden kirjeisiin lainkaan. Lisäksi kaikista opiskelijoiden viittauksista $(n=259)$ kanssaopiskelijoiden kirjeisiin valtaosa (86\%) oli joko argumentoinnin kannalta epärelevantteja (mm. kysymyksiä, vastauksia, vetoomuksia) tai yksimielisyyttä ilmentäviä.

Kritiikin vähyys kävi ilmi myös opiskelijoiden 
( $n=224)$ vastauksista tehtävään, jossa heitä pyydettiin kommentoimaan kirjallisia argumentteja. Vaikka argumentin sisältämä väittämä ja perustelut oli tehtävässä muotoiltu tarkoituksellisesti virheellisiksi, jopa provosoiviksi, vain noin viidennes $(21 \%)$ opiskelijoista reagoi kommenteissaan näihin virheellisyyksiin. Tutkimustulokset kuvaavat aikaisempien tutkimusten (Steffensen 1996) tapaan suomalaisen yliopisto-opiskelijan haluttomuutta ja taitamattomuutta esittää kritiikkiä muiden esittämiä näkemyksiä kohtaan.

\section{Sähköposti tuki argumentointi- taitojen kehittymistä}

Vaikka opiskelijoiden taito argumentoida osoittautuikin heikoksi, argumentoinnin harjoitteleminen sähköpostin avulla edisti taitoja. Taitojen kohenemiseen viittaa ensinnäkin se, että loppumittauksessa taitojen tasoa mitanneilla 12:1la muuttujalla kolmella sähköpostiopiskelijat saivat tenttimällä opiskelleita korkeamman pistemäärän, kun ero yhdellä muuttujalla oli tenttineiden eduksi. Keskiarvojen erot muilla muuttujilla eivät olleet tilastollisesti merkitseviä. Toiseksi opiskelijoiden sähköpostikirjeiden argumentaation taso kohosi opiskelun aikana: jälkimmäisten kolmen viikon aikana lähetettyjen kirjeiden argumentaation keskimääräinen taso oli korkeampi kuin ensimmäisten kolmen viikon aikana lähetettyjen. Sähköpostin käyttö myös tuki ja rohkaisi opiskelijoita ottamaan osaa keskusteluihin ja esittämään omia mielipiteitään. Tämän puolesta puhuu se, että huolimatta opiskelijoiden välisen vuorovaikutuksen vähyydestä jokainen opiskelija osallistui vuorovaikutukseen viittaamalla opiskelun aikana ainakin kahdesti jonkun toisen opiskelijan kirjeeseen. Lisäksi yli puolet (17/30) opiskelijoista kertoi esittäneensä sähköpostikirjeissään sellaisia asioita ja näkemyksiä, joita he eivät olisi esittäneet kontaktiopetustilanteessa. Tulos viittaa siihen, että sähköpostiympäristö tarjoaa mahdollisuuden rohkeampien mielipiteiden esittämiseen verrattuna tilanteisiin, joissa ihmisten välinen vuorovaikutus on välitöntä.

\section{Sähköpostikeskustelut olivat motivoivia ja rakentavia}

Tulosten mukaan sähköpostiopiskelu otettiin myönteisesti vastaan ja sitä pidettiin motivoivana ja innostavana tapana opiskella sisältöjä. Suurin osa opiskelijoista ilmoitti, että heidän opiskelumotivaationsa oli hyvä (25/30) ja että he kokivat ryhmän tukeneen heitä opiskelun aikana (29/30). Niinikään valtaosan mielestä keskustelujen aikana esitetty kritiikki muiden opiskelijoiden kirjeitä kohtaan oli rakentavaa $(18 / 30)$ ja toisten esittämiä näkemyksiä käsiteltiin hienotunteisesti (25/30). Sähköpostin avulla opiskelleista jokainen oli myös halukas osallistumaan uudestaan vastaavanlaiseen opiskeluun myöhemmin. Sähköpostiympäristön luoma tasa-arvoinen ja vapaa opiskeluilmapiiri mainittiin myös yleisesti $(11 / 30)$ yhtenä sähköpostiopiskelun etuna.

Opiskelijoiden myönteiseen palautteeseen uudesta opiskelutavasta lienee osaltaan vaikuttanut uuden tekniikan uutuudenviehätys sekä se, että sähköpostiopiskelijat oli valittu niistä, jotka olivat halukkaita osallistumaan kokeiluun. Palaute ei varmaankaan olisi ollut yhtä myönteistä, mikäli kokeiluun osallistuneet olisi valittu satunnaisesti. Sähköpostiopiskelun puutteena opiskelijat toivat esiin sen työläyden: Yksistään kaikkien lähetettyjen kirjeiden lukeminen on työlästä. Toisaalta toisten näkemysten kommentointi ja omien perusteltujen mielipiteiden esittäminen edellyttää aktiivista ja pohtivaa otetta opiskeluun. Koska keskusteluun ja ajatusten vaihtoon perustuva opiskelu ei ole kovinkaan tuttua suomalaiselle yliopisto-opiskelijalle, tällainen opiskelu luultavasti koettiin työläänä ja aikaa vievänä. Sähköpostiopiskelun heikkoutena opiskelijat kokivat myös sen, että kurssin aikana ei järjestetty yhteisiä tapaamisia. Sosiaaliset kontaktit muiden opiskelijoiden kanssa yleensä lisäävät yhteenkuuluvuuden tunnetta ja myös edistävät opiskelumotivaatiota ja opiskeluviihtyvyyttä. Sähköpostin käytön ongelmana voidaankin pitää sitä, että se tarjoaa tällaiselle sosiaaliselle toiminnalle puutteelliset mahdollisuudet. 


\section{Sähköpostiopiskelu tuki konstruktivistista oppimista}

Keskeisiä sähköpostiopiskelua luonnehtivia piirteitä olivat opiskelijoiden itseohjautuvuuden ja aktiivisuuden painottuminen. Näitä ilmensivät tulokset, joiden mukaan opiskelijoista valtaosa pyrki kommentoimaan aktiivisesti muiden lähettämiä kirjeitä (21/30), ylläpitämään keskusteluja pyrkimällä osallistumaan väittelyihin (19/30) sekä luomaan keskusteluja tuomalla esiin uusia näkökulmia asioihin (16/30). Kaikki sähköpostiopiskelijat ilmoittivat myös pyrkineensä esittämään paljon omia ajatuksiaan ja mielipiteitään opiskelun aikana. Opiskelijoiden mielestä, merkittävin sähköpostin käytön etu oli mahdollisuus työskennellä oman aikataulun mukaisesti.

Myös aiemmissa tutkimuksissa riippumattomuus ajasta ja paikasta (Hiltz 1990) sekä mahdollisuus kriittiseen keskusteluun (Saunders \& Heyl 1988) on todettu sähköpostiopiskelun keskeisiksi eduiksi. Itseohjautuvuuden tärkeys kriittisen keskustelun aikaan saamisen kannalta korostui erityisesti niissä sähköpostiryhmissä, joissa opiskelijat valitsivat itse keskusteluaiheet ja huolehtivat keskustelujen etenemisestä: näissä ryhmissä vasta-argumentointi osoittautui yleisemmäksi ja vasta-argumentaation taso paremmaksi kuin tutor-johtoisissa ryhmissä. Itseohjautuvuuden ja aktiivisuuden ohella sähköpostiopiskelussa painottui opiskelijoiden pyrkimys asioiden ymmärtämiseen tähtäävään opiskeluun: Lähes kaikki opiskelijat (28/30) ilmoittivat pyrkineensä ottamaan kantaa kurssikirjoissa esitettyihin asioihin. Lisäksi opiskelun etuna opiskelijat toivat esiin sen, että opiskelutapa ei ainoastaan tarjonnut mahdollisuutta, vaan myös pakotti ajattelemaan ja reflektoimaan sisältöjä.

Tutkimustulokset viittaavat siihen, että sähköpostiopiskelua voidaan luonnehtia konstruktivistisen oppimisnäkemyksen periaatteiden mukaan eteneväksi opiskeluksi. Keskeistä konstruktivistisessa oppimisessa on se, että jokainen opiskelija joutuu viime kädessä itse rakentamaan tietonsa ja kuvansa maailmasta. Tässä prosessissa olennaista on uuden tietämyksen rakentaminen sen pohjalle, mitä jo aiemmin tiedetään kulloinkin käsiteltävästä aiheesta ja siihen läheisesti liittyvistä sisällöistä. Olennaisia konstruktivistista oppimista ohjaavia periaatteita ovat oppijoiden oman aktiivisuuden ja oppimisen sosiaalisen luonteen painottaminen sekä pyrkimys asioiden ymmärtämiseen. Rauste-von Wrightin ja von Wrightin (1996, 36-37) mukaan oppijan ajatusprosessit avautuvat ja eksplikoituvat niin oppijalle itselleen kuin kanssaoppijoillekin vuorovaikutuksessa muiden kanssa. Tämä mahdollistaa ajatusten reflektoimisen ja työstämisen sekä itsenäisesti että yhdessä toisten kanssa. Sähköpostiopiskelu perustui pitkälti opiskelijoiden omaan aktiivisuuteen ja keskinäiseen vuorovaikutukseen. Sähköpostikirjeitä laatiessaan opiskelijat hyödynsivät aiempaa tietämystään käsitellyistä aiheista sekä kartuttivat ja organisoivat uudelleen aiempia tietojaan vuorovaikutuksessa esiin tulleen uuden informaation pohjalta. Lisäksi sähköpostiopiskelun keskeinen piirre on se, että opiskelu perustuu kirjalliseen vuorovaikutukseen. Emigin (1977) mukaan kirjoittaminen edistää ajattelun taitoja. Hän korostaa sitä, että kirjoittaminen tekee ajattelumme näkyväksi ja mahdollistaa näin vuorovaikutuksen ajatustemme kanssa, jolloin niitä voidaan jatkuvasti muokata. Kirjoittamiseen perustuva sähköpostiopiskelu edellyttää näin oppisisältöjen aktiivista pohtimista ja sisältöjen ymmärtämistä painottavaa otetta opiskeluun.

\section{LOPUKSI}

Sähköpostin käyttö paitsi informaation välityskanavana myös keskustelufoorumina näyttää edellä kuvatun tutkimuksen valossa perustellulta: sähköposti tuki argumentoivan ja kriittisen vuorovaikutuksen aikaansaamista opiskelijoiden välille. Yliopisto-opinnoissa erityisesti perinteisten kirjatenttien osittainen korvaaminen sähköpostikeskusteluilla näyttäisi tutkimustulosten valossa mielekkäältä. Kriittinen keskustelu näyttää soveltuvan sellaisten oppisisältöjen opiskeluun, jotka tarjoavat mahdollisuuden asioiden kyseenalaistamiselle ja tar- 
kastelemiselle useista eri näkökulmista keskustelijoiden erilaisen arvo- ja kokemusmaailman pohjalta. Tästä huolimatta tällaisia sisältöjä useimmiten opiskellaan kirjoja lukemalla ja tenttimällä.

Tenttimisen ongelma on myös se, että tentteihin luetaan usein vain suoritusmerkinnän saamiseksi, jolloin asioiden ymmärtämiseen tähtäävä opiskelu jää monesti vähemmälle huomiolle. Omien mielipiteiden esittämiseen ja vuorovaikutukseen perustuva sähköpostiopiskelu näyttäisi motivoivan opiskelua ja tukevan asioiden syvällistä käsittelyä ja argumentointitaitojen ja kriittisen ajattelun kehittymistä.

Vaikka sähköpostiympäristössä vuorovaikutus usein lisääntyykin monien tasa-arvoisen keskustelun esteiden kadotessa, sähköpostia käytettäessä voi tilalle kuitenkin syntyä uudenlaisia esteitä. Sähköposti kirjalliseen ilmaisuun perustuvana vuorovaikutuskanavana suosii aktiivisia ja taitavia kirjoittajia. Tämä voi aiheuttaa sen ongelman, että innokkaat ja taitavat kirjoittajat saavat mielipiteensä kuuluviin ja taidoiltaan heikommat tyytyvät vain seuraamaan taitavampien kirjoittelua ja ajatustenvaihtoa. Myös tutkimuksissa (Romiszowski \& de Haas 1989) on todettu, että tasa-arvoisuus sähköpostikeskustelussa koskee usein vain keskustelun alkuvaihetta - keskustelujen jatkuessa pidempään osallistujat jakautuvat erilaisen statuksen ja roolin mukaisiin ryhmiin, joiden keskusteluaktiivisuus eroaa toisistaan.

Sähköpostiopiskelun ongelmaksi voi muodostua myös se, että sähköpostikirjoittelu edistää ensisijaisesti vain kirjallisen ilmaisun ja argumentoinnin taitoja. Suullisen argumentoinnin taitojen edistämistä voidaan kuitenkin pitää kirjallisen ilmaisun ohella keskeisenä korkeakouluopiskelun tavoitteena. Suullista perustelutaitoa tarvitaan esimerkiksi tieteellisissä kokouksissa ja tutkijatapaamisissa sekä yrityselämässä neuvottelujen kognitiivisena apuvälineenä. Opiskelijoiden argumentointitaitojen kehittämiseksi yliopiston opiskelumuotoja pitäisikin kehittää siten, että sekä suullinen että kirjallinen vuorovaikutus muiden kanssa ja asioiden aktiivinen pohdinta painottuisivat nykyistä enemmän.

Pohdittaessa tutkimuksen merkitystä työelämän aikuiskoulutuksessa tarkastelu on mielekästä liittää oppivasta organisaatiosta käytävään keskusteluun. Marsick ja Watkins (1994) korostavat yhtenä oppivien organisaatioiden kehittymisen esteenä ihmisten kykenemättömyyttä muuttaa vallitsevia ajattelutapoja ja mentaalisia malleja. Dialogia he pitävät organisaatioiden keskeisenä strategiana tämän esteen poistamiseksi. Olennaista oppivan organisaation kehittymisen kannalta on etsiä niitä keinoja, joilla organisaation jäsenten välisen vuorovaikutuksen määrää voidaan lisätä ja sen laatua kehittää. Näin on mahdollista edistää organisaation kykyä muuttaa niitä ajattelutapoja ja käytänteitä, jotka eivät ole tarkoituksenmukaisia enää nykypäivänä.

Tärkeätä oppivan organisaation kehittymisen kannalta on myös verkostoituminen organisaation ulkopuolisten tahojen kanssa. Lehtinen ja Palonen (1997) korostavat verkoston käyttövoimana monenvälistä vaihtoa. Tällöin heidän mukaansa se, mitä yhteistyö antaa, saadaan usein jostain muualta kuin sieltä, jonne oma anti kohdistuu. Verkostoitumisen seurauksena vuorovaikutus muiden kanssa monipuolistuu ja rikastuu, mikä lisää organisaation mahdollisuuksia jatkuvaan oppimiseen.

Verkostojen luomisen ja ylläpitämisen yksi keskeinen väline on sähköposti. Aikaan ja paikkaan sitoutumattomana välineenä sähköposti mahdollistaa organisaation joustavan vuorovaikutuksen niin kansallisten kuin myös kansainvälisten tahojen kanssa. Ulkopuolisten yhteyksien lisäksi sähköpostin avulla on mahdollista rikastuttaa myös organisaation sisäistä vuorovaikutusta. Sähköpostia käyttäen voidaan luoda uudenlaisia ympäristöjä yritysten työntekijöiden keskinäiselle sekä työntekijöiden ja johdon väliselle keskustelulle. Sähköpostiympäristö tarjoaa mahdollisuuden tasa-arvoiselle, asia-argumentteihin perustuvalle keskustelulle, jossa esimerkiksi keskusteluun osallistujien sukupuoli, koulutus tai ammatillinen status ei vaikeuta vuorovaikutuksen aikaansaamista samassa määrin 


\section{PULKKINEN}

kuin välittömissä vuorovaikutustilanteissa. Keskustelu voidaan toteuttaa myös anonyyminä, mikä usein edelleen alentaa kynnystä esittää mielipiteitä ja ottaa kantaa asioihin. Tällöin avoin keskustelu esimerkiksi organisaation tavoitteista ja toimintakulttuurista on, niin haluttaessa, mahdollista. Sähköpostin käytön kehittämistä voidaankin pitää yhtenä varteenotettavana vaihtoehtona haluttaessa edistää vuorovaikutusta ja argumentoivan keskustelukulttuurin kehittymistä niin yliopisto-opinnoissa kuin työelämässä.

\section{Iöhtrest}

COLLINS, M. (1997) A successful experiment with an electronic bulletin board in a large class. Journal of College Science Teaching 26, 3, 189-191.

EMIG, J. (1977) Writing as a mode of learning. College Composition and Communication 28, 2, 122-128.

HILTZ, S. R. (1990) Evaluating the virtual classroom. Teoksessa L. Harasim (toim.) Online education. Perspectives on a new environment. New York: Praeger, 133-183.

HIRSJÄRVI, S., BÖÖK, M. L. \& PENTTINEN, L. (1996) 'Sit me ruvetaan oleen tieteellisiä subjekteja' - Tieteellisyyden rakentuminen opiskelijadiskurssissa. Teoksessa L. Laurinen, M-R. Luukka \& K. Sajavaara (toim.) Seminaaridiskurssi-diskursseja seminaarista. Jyväskylän yliopisto. Soveltavan kielentutkimuksen keskus. Jyväskylän yliopistopaino, 163-190.

LEHTINEN, E. \& PALONEN, T. (1997) Tiedon verkostoituminen - haaste asiantuntijuudelle. Teoksessa J. Kirjonen, P. Remes \& A. Eteläpelto (toim.) Munttuva asiantuntijuns. Koulutuksen tutkimuslaitos. Jyväskylän yliopisto, 103-121.

LITTLEFIELD, R. S. (1995) Teaching argumentation and debate skills to young children: bridging theory and practice. Teoksessa F. H. van Eemeren, R. Grootendorst, J. A. Blair \& C. A. Willard (toim.) Proceedings of the third ISSA conference on argumentation. Reconstruction and application. Vol. III. Amsterdam: International Centre for the Study of Argumentation, 287-296.

MARTTUNEN, M. (1997a) Studying argumentation in higher education by electronic mail. Jyväskylä, University of Jyväskylä. Jyväskylä studies in education, psychology and social research 127 .

MARTTUNEN, M. (1997b) Vuorovaikutus sähköpostiopiskelussa yliopisto-opinnoissa. Teoksessa E. Lehtinen (toim.) Verkkopedagogiikka. Helsinki: Edita, 112-127.

MARSICK, V. J. \& WATKINS, K. E. (1994) The learning organization: an integrative vision for HRD. Teoksessa A. Brooks \& K. Watkins (toim.) Proceeding of the Academy of buman resource development conference, San Antonio, Texas, March 2-6, 136-141.

MAURANEN, A. (1993) Opiskelijan diskurssimaailmat vaibto-opiskelijoiden perspektiivi. Teoksessa H. Jalka- nen \& L. Lestinen (toim.) Korkeakouluopetukesen kriisi. Artikkelikokoelma Jyväskylässä 19.-20.8.1993 järjestetystä korkeakoulutuksen tutkimuksen $\mathrm{V}$ symposiumista. Jyväskylä: Kasvatustieteiden tutkimuslaitos, 169-188.

PUGH, S. L. (1993) Using case studies and collaborative computer-assisted commu-nication to support conceptual learning in a teacher-education course on critical reading. Educational Technology 33, 11, 30-38.

RAUSTE-VON WRIGHT, M. \& VON WRIGHT, J. (1996) Oppiminen ja koulutus. Porvoo: WSOY.

ROMISZOWSKI, A. J. \& DE HAAS, J. A. (1989) Computer mediated communication for instruction: Using e-mail as a seminar. Educational Technology 29, 10, 7 - 14.

RUBERG, L. F., MOORE, D. M. \& TAYLOR, C. D. (1996) Student participation, interaction, and regulation in a computer-mediated communication environment: a qualitative study. Journal of Educational Computing Research 14, 3, 243-268.

SAUNDERS, C. S. \& HEYL, J. E. (1988) Evaluating educational computer conferencing. Journal of Systems Management 39, 4, 33-37.

STEFFENSEN, M. S. (1996) How Finns and Americans persuade. Paper presented at the 11th World Congress of Applied Linguistics (AILA 96), 4-9 August. Jyväskylä, Finland.

TELLA, S. (1992) Talking shop via e-mail: a thematic and linguistic analysis of electronic mail communication. University of Helsinki. Department of Teacher Education. Research report 99.

TELLA, S. (1994) Telematiikka ja verkostuva oppimisympäristö - haasteita aikuiskasvatukselle. Aikuiskasvatus 14, 4, 257-261.

TERENZINI, P. T., SPINGER, L., PASCARELLA, E. T. \& NORA A. (1995) Influences affecting the development of students' critical thinking skills. Research in Higher Education 36, 1, 23-39.

TOULMIN, S., RIEKE, R. \& JANIK, A. (1984) An introduction to reasoning. New York: Macmillan.

Kijoittaja väittelikasvatustieteiden tohtoriksi 7. 6. 1997 J yväskylän ylio pistossa. Väitöskijan a iheena oliStudying argumentation in highereducation by elec tronic mail. Artikkeli sa a pui 15.9.1997 ja se hyväksyttiin julka istavaksi toimituskunnan kokouksessa 10.11. 